\title{
Quality Deterioration of Postharvest Fruits and Vegetables in Developing Country Pakistan: A Mini Overview
}

\author{
Khurshid Ahmad ${ }^{\mathrm{a}}$ Mahideen Afridi ${ }^{\mathrm{b}}$ Nasir Ali Khan ${ }^{\mathrm{c}}$, Azeem Sarwar ${ }^{\mathrm{d}}$ \\ ${ }^{a}$ College of Food Sciences and Engineering, Ocean University of China \\ Qingdao, Shandong Province, P.R. China \\ *Corresponding Author: Email; khurshid.msbt361 [AT] iiu.edu.pk \\ ${ }^{b}$ National Center for Bioinformatics, Quaid-i-Azam University \\ Islamabad, Pakistan \\ Email; mahidkhanafridi [AT] gmail.com \\ ${ }^{c}$ Department of Microbiology, Quaid-i-Azam University \\ Islamabad, Pakistan \\ Email; nasirkhan [AT] bs.qau.pk \\ ${ }^{\mathrm{d}}$ Department of Biological Sciences, International Islamic University \\ Islamabad, Pakistan \\ Email;azeem.msbt442 [AT] iiu.edu.pk
}

\begin{abstract}
Post-harvest losses relate to the degradation in the quantity and quality of the crop's products from harvesting to consumer usage. In many developing countries, like Pakistan, the post-harvest loss is a problem of food security and is of concern to everyone. Inappropriate handling of agricultural products after harvest may cause quality and quantity losses. It also accounts for the increasing prices of agricultural products in Pakistan. The total production of vegetables and fruits in Pakistan is nearly 13.764 million tons, and it is estimated that 35\% to $40 \%$ of vegetables and fruits were wasted after harvesting. Severe losses and deterioration of vegetables and fruits occurred mainly during harvesting, along with distribution, transportation, and storage. The important reasons for post-harvest losses include mechanical damage, poor handling, microorganisms (bacteria, fungi), unawareness and lack of modern technologies, time management, insects, and mites. Reduction of post-harvest losses is the main goal of the agricultural sector. Training and educational initiatives could be one of the best strategies for minimizing post-harvest losses. The main objective of this review is, to explain the major production, quality deteriorations of vegetables and fruits, and the causes of post-harvest losses in Pakistan. It can be applied as a positive indication because all bodies involved will strive to implement efficient and effective approaches and policies to address the existing problems.
\end{abstract}

Keywords--- Fruits Vegetables, Post harvesting, Food losses, Quality deterioration

\section{INTRODUCTION}

The post-harvest losses of foodstuffs are not a new-fangled it has always been a problem for human beings. In the modern era of quickly boosting population in most developing countries where nutrition is already lower, there is some increasing perseverance in doing the best work to maintain food quality supply to mend hunger and malnutrition. Losses of vegetables and fruits occur from field to fork, and the magnitude of losses that occur at a later stage is strongly affected even by pre-harvest practices $[1,2]$. Postharvest loss is the problem of food security in many developing countries, like Pakistan, and it is everyone's concern. Severe post-harvest vegetable, fruit loss and deterioration in quality occurred mainly during harvesting, processing, storage, transportation, and marketing, driving to a reduction in outputs for producers, lack of food, malnutrition, effects on people's and country's economy. Due to the quality of the crops, there is a great magnitude of loss in vegetable and fruit crops compared with others. Many scientific studies have been reported on vegetables and fruits that have various causes and the magnitude of the loss especially. This could be due to limitations of managerial, financial, and technical knowledge in harvesting techniques, refrigeration, and storage facilities in tough climatic conditions, packaging, infrastructure, and marketing strategy. To minimize such issues, correct farming methods, such as the general principles for maximizing the shelf-life of these products, must be account. Humidity, temperature, and efficient measures for avoiding such losses should be properly managed [2, 3, \& 4]. 
Many post-harvest research studies have so far concentrated on grains and other robust goods, which are stored dry, and a comprehensive technology has been developed to address these concerns. Therefore, since most countries understand that post-harvest food losses are complicated, it requires a commitment to a holistic solution, including local communities, multiple organizations, and associations [5]. Less work has been performed on the perishable food crops, yet in numerous parts of the sub humid and humid tropics, they are of great significance and contribute to the staple carbohydrate lot of the diets in developing countries $[6,7]$. Pakistan has a wide range of agro-ecological conditions, including temperate, tropical, and subtropical regions with a diverse variety of horticultural crops. They are also highly economically important crops with a prospect of export markets, local consumption, processing, and playing an important role in poverty reduction and food security. They are also important sources of minerals, nutrients, and vitamins equally beneficial for human health [8, $9,10, \& 11]$.

\section{DETERIORATION AND LOSSES OF POST-HARVEST FRUITS AND VEGETABLE}

In a variety of vegetable and fruit crops, Pakistan has a comparative advantage owing to its cheap labor, favorable environment, access to export markets such as the Middle East and Asia. Still, vegetable and fruit production are far less advanced than staple grain production. Because postharvest control of vegetables and fruits has not been provided enough attention, significant loss occurs at harvest and postharvest phases and most postharvest losses are difficult to measure for horticultural produce. Although Pakistan's horticultural sector is growing, little and insufficient support has been reported for improving and reducing postharvest loss and deteriorating the quality of horticultural crops. An estimation of 35 to 40 percent of postharvest horticultural crop losses in Pakistan has been reported. Such losses during harvest are thus an important source of food loss and could be observed from the perspectives of poverty reduction and food security in the world as such losses have a direct effect on the country's people's livelihood and economy. Several researchers reported the most prevalent causes of postharvest losses are the lack of processing to remove pre-storage defects, use of insufficient packaging materials, harsh handling, improper temperature and cooling control [2, 12, \& 13].

\section{PRODUCTION AND LOSSES OF POSTHARVEST BANANA IN SINDH AND PUNJAB}

Such perishable staple foods (vegetables and fruits) are cultivated quite mostly from small-scale subsistence-level processes, and the techniques used in both utilization and production are usually simple and focused on long-established conventional practice. Fruits, root crops, and vegetables are living parts of plants that contain more water, and after harvest, they sustain their living processes. Vegetables and fresh fruits are crops that contain high water content and are subjected to mechanical injury and desiccation. Post-harvest survival depends on the rate of use of accumulated food reserves and the rate of water loss. Once the water and food supplies are depleted, the commodity dies and decays. So that these perishable goods require careful handling during harvesting and postharvest processing, to minimize commodity degradation as much as possible during the time among harvest and utilization. It is reported that the total post-harvest of bananas amounted to Pakistan has been 154,825 ton from 34, 830 hectares per year shown in Figure 1: The most contribution coming from Sindh and Punjab provinces about $90 \%$ banana were cultivated in various districts of Sindh province such as Tando, Nawabshah, Naushero Feroz, Badin, Mirpurkhas, Thatta, Hyderabad, and north part of the Sindh as Khair Pur were 32,236 hectares out of whole 34, 830 hectares in Pakistan. In Punjab province, banana cultivation is less than Sindh its approximately $10 \%$ as 1,389 hectares, in such a way banana production in Sindh was recorded at 127,426 ton and on another hand, Punjab production was recorded as 9, 373 ton. In addition, post-harvest loss assessment of vegetables and fruits was conducted in Pakistan, resulting in higher post-harvest losses of bananas and deterioration of quality were mainly attributable to chilling injuries, bunchy top virus, poor transportation, packing, handling, lack of awareness, and the use of poor managements as well marketing strategies to vend their vegetables and fruits $[11,14, \&$ $15]$.

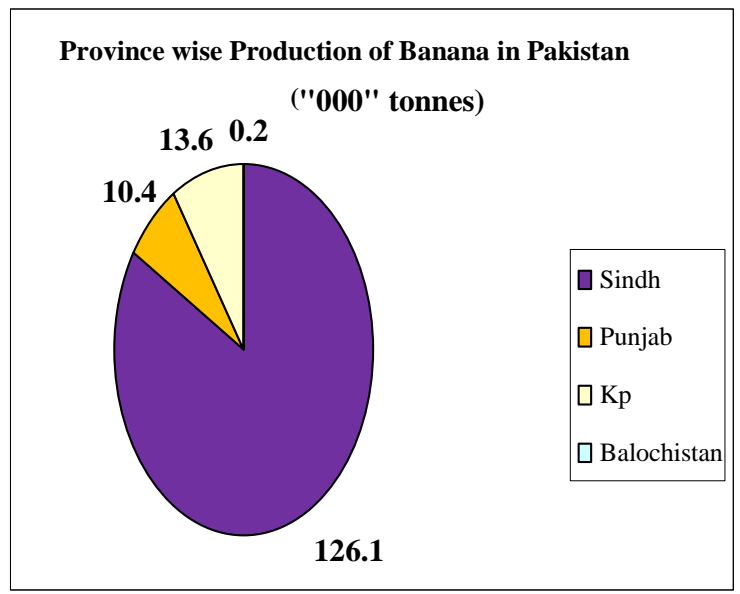

Province wise Area of Banana in Pakistan

("000" hectar)
1.60 .70 .4

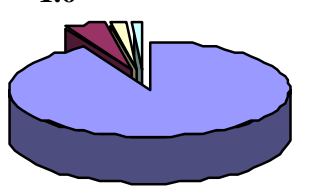

32.2

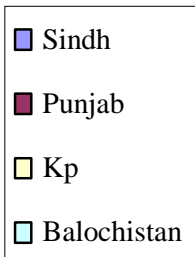

$\square$ Balochistan
Figure 1: Indicates province and province wise area of Bananas in Pakistan (Shahzad et al., 2019). 


\section{FABRICATION AND LOSSES OF CROPS, FRUITS, VEGETABLES IN KPK AND BALUCHISTAN}

Pakistan is the developing country, where nearly $58 \%$ of the total output of vegetables and $45 \%$ of the harvested fruit is found. In Pakistan fruit and vegetables, play a key role, in economic growth as they produced $12 \%$ of agricultural GDP. The fruits production in Pakistan are Guava, mango, and orange at the rate of 7\%, 27\%, and 31\% respectively. In Pakistan agro-climatic conditions different from tropical region to moderate region, where 40 different varieties of vegetables and 20 kinds of fruits were produced. Pakistan are placed in those developing countries list where the losses of many fruits and vegetables occurred due to unawareness about the advanced equipment, technology, implementing the old tools, techniques, and process, such types of losses are very less in developed countries. However, the total production of vegetables and fruits in Pakistan are nearly 13.764 million tons shown in Table 1 and it is estimated that 35-40 \% postharvest fruits and vegetables were wasted $[12,16,17, \& 18]$.

Table 1: Losses of Crops, Fruits, and Vegetables in Pakistan

\begin{tabular}{ccc}
\hline Crops/Fruits/Vegetables & Percentage of losses & Reference \\
\hline Harvested crop & $15-20 \%$ loss at time management \\
Rice & $15 \%$ \\
Wheat & $10 \%$ \\
Fruit/vegetables & $20 \%$ \\
Tomato & $5-8 \%$ \\
Harvesting fruit/vegetables & $6 \%$ \\
Almond, walnuts & $23 \%$ \\
Peach & $28.84 \%$ \\
Banana & $50 \%$ & {$[11,12,16]$} \\
Mulberry, mango, apples, & \\
apricots, cherry & \\
\hline
\end{tabular}

Major post-harvest losses and degradation of vegetables and fruits occurred primarily during processing accompanied by distribution, transport, and storage. Poor use of quality materials and equipment caused huge damage to vegetables and fruits from physiological, mechanical, and pathological aspects. Likewise, there is a post-harvest vegetable and fruit loss evaluation study in Swat, KPK Pakistan reporting that inadequate storage, transportation, and discouraging market conditions are the foremost cause of post-harvest failures.

In Pakistan two main provinces Baluchistan and Khyber Pakhtunkhwa have grown various varieties of fruits and vegetables such as cherry, peaches, pears, walnuts, grapes, persimmons, apples, plum, guava, apricots, plums, soybeans, onions, potatoes, cucumbers, and tomatoes. The main producing regions of fruits especially plum are Pishin, Peshawar, Nowshera, Mardan, Mastung, Kalat, Quetta, and Swat Pakistan. Plums are the second important fruits that are found in many varieties after peach in Pakistan. The total production of plum in Pakistan is 67,000 tons, which are 17th position in the world ranks. The main providing province of Pakistan, Khyber Pakhtunkhwa is $47 \%$ in the whole production, where Swat regions contribute $17 \%$ of the plum fruits (GoP, 2009), [12, 13, 20, \& 21].

Producers (farmers), wholesalers, retailers, researchers, and other public and non-governmental organizations need to have a clear understanding of post-harvest losses, causes of post-harvest losses, and quality deteriorations in Pakistan's vegetable and fruit crops. Hence, the main purpose of this review is to explain the major production, causes and postharvest losses of fruit and vegetable quality deterioration in Pakistan. This can be applied as a great indication since all the concerned communities should aim to develop efficient and effective strategies and policies to solve existing problems. Here we outline the amount of post-harvest losses of fruits and vegetables in Pakistan at collection, farm, retail level and wholesale which are assumed to be affected by several factors, including economic, social and infrastructure as shown in Figure 2: 


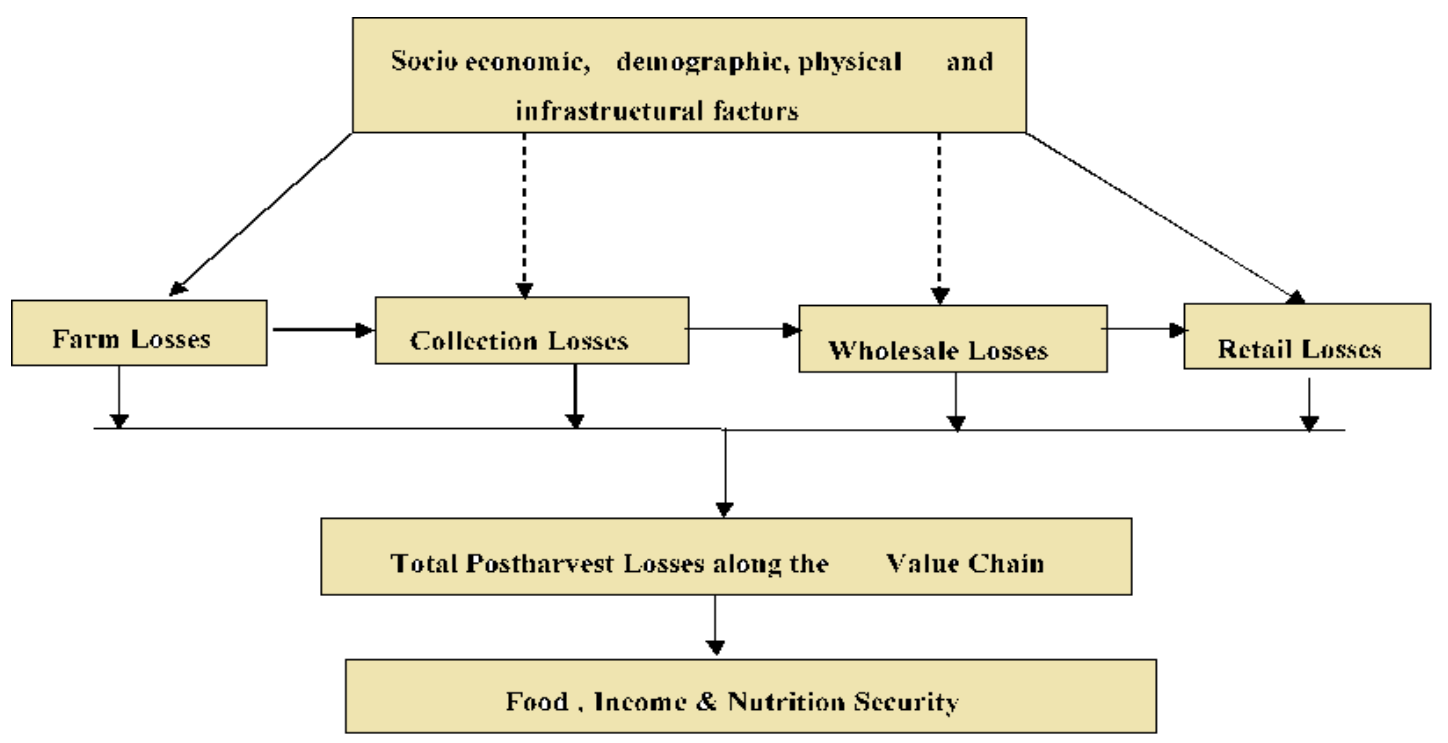

Figure 2: Conceptual framework for post-harvest losses of fruits and vegetable in Pakistan

\section{LANDSCAPE OF THE POSTHARVEST CROPS}

Pakistan is included among the developing nations in Asia. Subtropical, tropical, and temperate vegetables and fruits have been grown in the country. The country has a comparative advantage in several horticultural products due to its high domestic demand, favorable climate, and cheap labor. Most production operations carried out by small-scale farmers and provided for sale in nearby markets. A variety of vegetables and fruits are cultivated, but not all produce reaches to the consumers $[2,21, \& 22]$.

Vegetable and fruit crops produce relatively high levels of moisture, larger in size and soft texture compared with legumes and cereals, and it is beneficial to sell immediately after the harvest. This is because the vegetables and fruits are alive and can lose water through transpiration and respiration. Researchers have also reported that vegetables are characterized by high metabolic activity and are known to have a short storage life. Unlike that of dry grains, the perishability quality and hugeness make horticultural crops hard to manage easily during the postharvest period [23, 24].

They required careful handling and the lack of optimal environmental conditions and adequate management of their storability the risk of failure increased. Therefore, leafy vegetables are more affected than the development of fruits and root crops and great care must be taken to reduce the risk of degradation during processing, shipping, storage, and marketing.

\section{INFECTION, PEST AND INSECTS PROBLEMS}

The bruised, damaged, and unhealthy parts of vegetables and fruits are the major causes of quality deterioration and postharvest loss due to the impact of pest and disease at the production level. Recently there is a report that the impact of cutworm is important to fruit crops such as tomatoes while the crops are at field level. The major mite pests and insects of tomato include potato tuber moth, African bollworm, whiteflies, tomato leaf miner/fruit borer, and spider mites which is responsible for ear wigs, leaf hoppers, cut worms, root grubs, thrips, mites, and flea beadles [25, 26].

\section{MARKETING STRATEGIES AND PROBLEMS}

Vegetable and fruit products are mostly produced by smallholder farms in Pakistan, and most farmers are selling their products on the local market, and a few are selling on both the surrounding market and the field so, the marketing situation is discouraging and unsatisfactory. The explanations for the unsatisfactory market situation suggested the higher availability of the commodity at one point, exploitation by middlemen, and sales of the goods on the farm and surrounding area. There is a research report on Khyber Pakhtunkhwa (kpk) province of Pakistan, where major post-harvest loss evaluation of vegetables and fruits that elaborated on the existence of the highest percentage loss for fruits during marketing that was on the various districts such as Kohistan, Swat, Battagram, Buner, Dir, and Chitral, as the fruits were marketed in the open space of the sun-exposed roadsides. Moreover, other researchers proclaimed that, large numbers of intermediaries in the marketing system, lack of demand to absorb production, lack of trading institutions to safeguard the rights and interests of farmers over their marketable goods, lack of cooperation between producers to improve their bargaining power and inadequate sellers ' pricing system as major problems for producers [27, 28]. 


\section{SHORTAGE OF ACCLAIM/ECONOMICAL}

Limited credit service for the horticultural sector in Pakistan and lack of credit providers on post-harvest horticultural crop handling to maintain product quality and extend product shelf-life were identified as country constraints. On the other hand, in many research reports in Pakistan, most of the respondents indicated that the causes of not taking part in the credit market were religion related [19].

\section{HANDING, SHIPPING, CARRYING, AND STORAGE PROBLEM}

For packaging use of smooth, ventilated, and safe cans is a very important factor in minimizing losses in the crops through processing, distribution, transportation, and storage. A study reports suggest that only 31.1 percent of shops that stored spoiled and physically injured fruits separately in the fruit management assessment conducted in Swat. Thus, in postharvest handling of horticultural products, the transportation system had loaded one over the other, subjecting the products to damage, injury, and ultimately shortening the product's shelf life. Mixed loads of bulk commodities are again a serious concern as the products have various responses to transpiration, temperature, ethylene, transportation, and dehydration, which altogether affect commodity durability by enhancing mechanical, chemical, physiological, and biological losses. According to the research reports 10.08 percent postharvest potato loss occurred in storage, and 3.98 percent in transport recorded in Swat districts of northern KPK region, Pakistan. Transport, inadequate packaging material, and lack of adequate storage facilities were reported as a factor of quality deterioration and post-harvest loss in vegetable and fruit in Pakistan. Scientists have described that the lack of a proper packing station and a farm storage facility means that perishable products are placed on the market instantly after harvesting without adequate packaging and primary processing Figure 3: Various containers such as baskets, sacks, wooden boxes, and plastic materials used to collect various products from farms during harvesting with inadequate handling, which increases the level of damage caused by the production. Packages must be vented and durable enough to prevent structural changes. If products are packed for ease of handling, wooden crates, waxed cartons, or rigid plastic containers are preferred to open baskets or bags, since when stacked, baskets and bags do not protect the products. Mixing unlike products and overfilling containers has been a major issue in postharvest. Most traders store unhealthy and injured produce along with normal ones and eventually come up against losses [12, 29, \& 30].

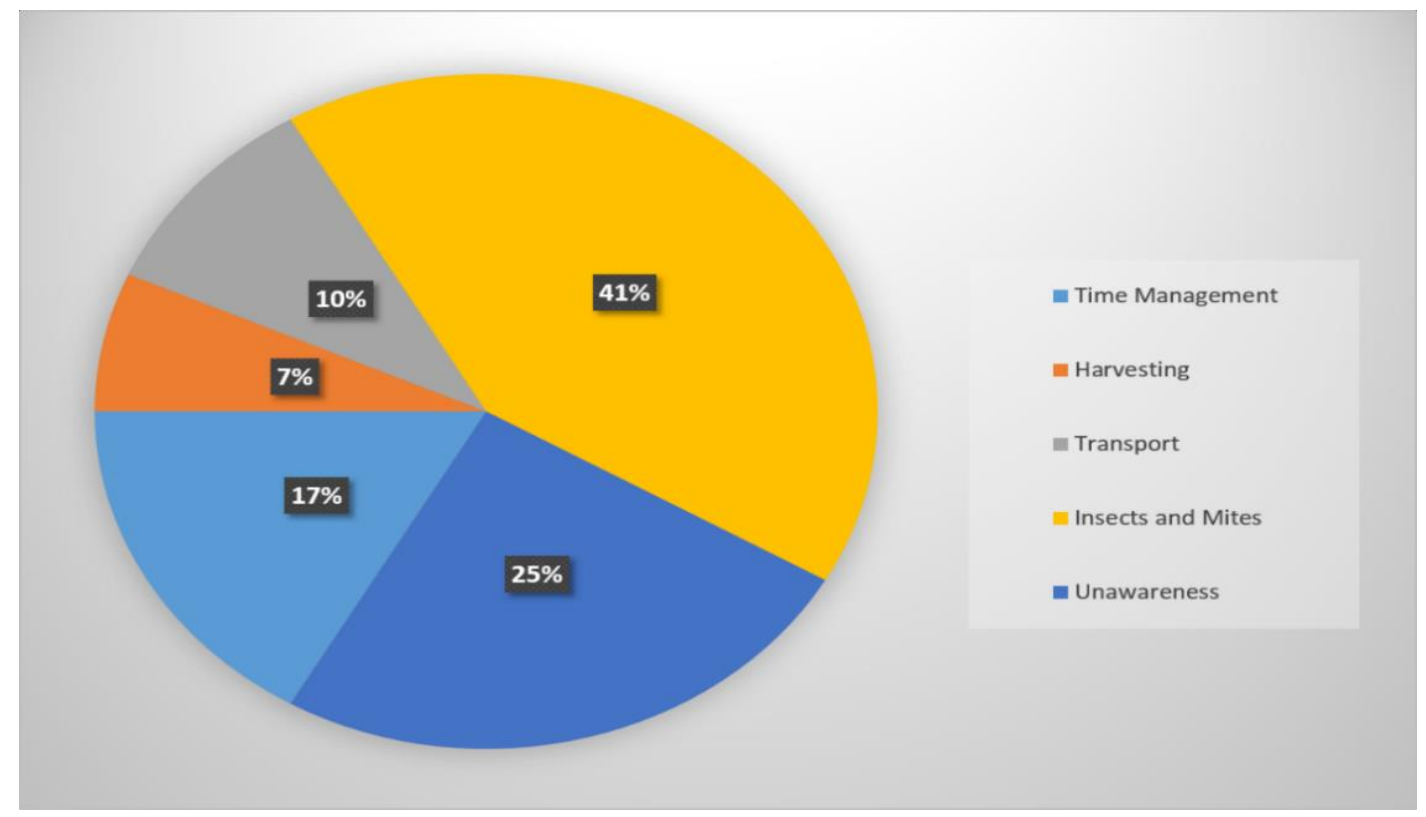

Figure 3: Postharvest Losses of Fruits and Vegetables through various Percentage in Pakistan (Dawn, 2001).

\section{PROCESSING AND IMPORTANCE ADDITIONAL PROBLEMS}

Many horticultural crops need simple processing technologies when conditions are not proper for storage or the immediate marketing of the fresh product. Small-scale handlers can use many processing methods, including canning, freezing, drying, preserving, fermenting, and juicing different factors involve in loss of fruits and vegetables shown in Figure 4: Vegetables and fruits may be dried and stocked for sale or use in the future. Fermentation is the widespread food preservation technique around the globe [31]. Vegetables and fruits can be frozen or canned, and fruits are often preserved in juice or sugar. Processed products must be properly stored and packed to reach their potential shelf-life of up to one year. Dry goods must be packed in air-tight containers (plastic or glass bottles or sealed plastic bags). Bottled and canned 
goods must be processed with enough heat using containers of high quality which provide good seals. Canned, dried, or bottled products are better kept in a cold, dark place [32, 33].

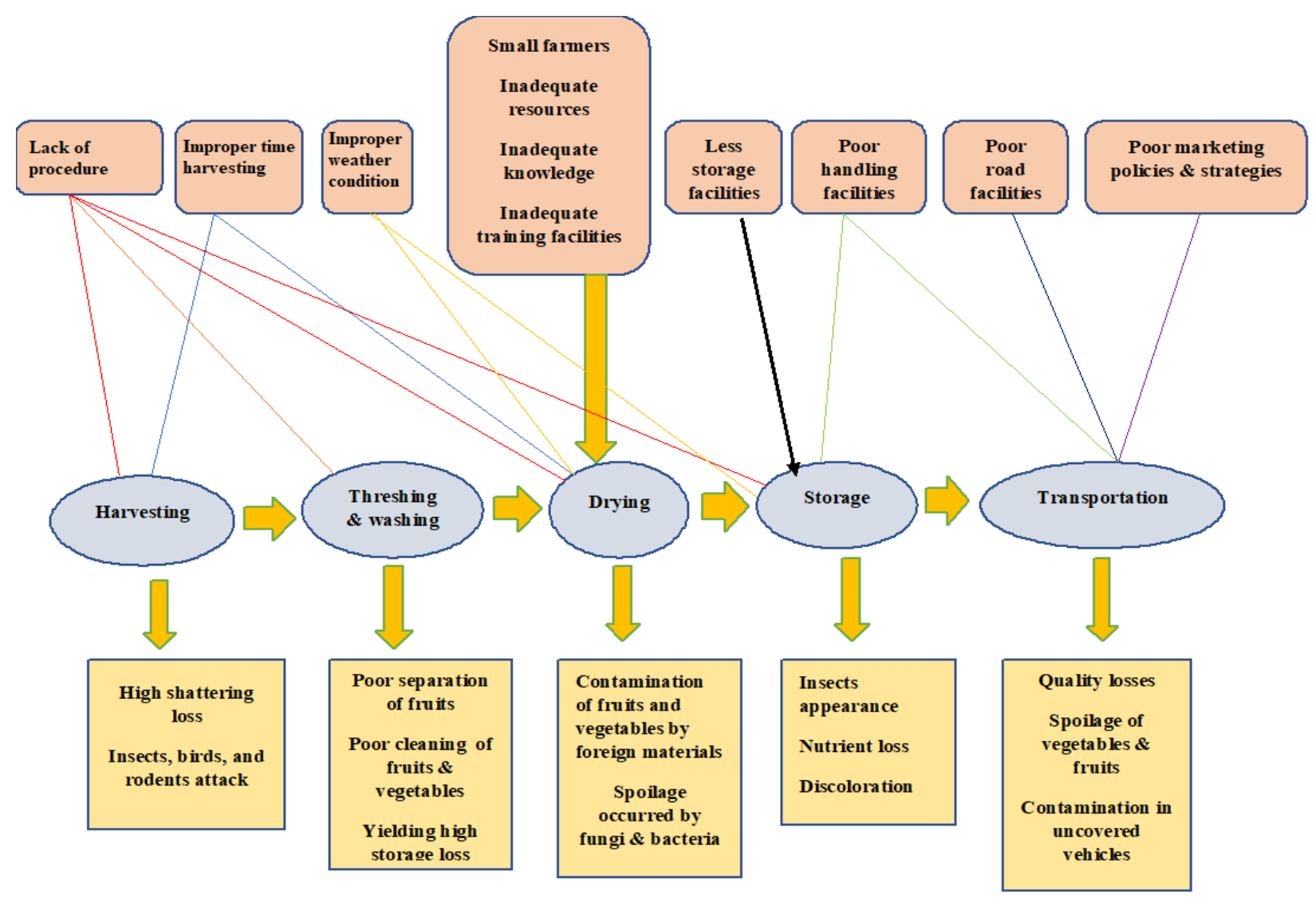

Figure 4: Different factors and losses type during supply of fruits and vegetables in develop countries like Pakistan

\section{CONCLUSION AND RECOMMENDATION}

Quality deteriorations and postharvest losses exist from field to fork, and even pre-harvest procedures and actions have a strong impact on the extent of losses that occur later. They may also be resulted using essential storage facilities. Hence, training and educational initiatives could be one of the best strategies to resolve the minimization of postharvest losses both in the field and during storage. Horticulturalists, extension workers, and development agents should have a complete understanding of the impacts and issues of postharvest loss and should be involved in training farmers to take care of controlling the losses. In general, postharvest technologies from different countries could be acclimated for economically important perishable horticultural crops with the assistant of government programs related to postharvest handling and government extension services.

\section{ACKNOWLEGMENTS}

We would like to thank Dr. Sayed Ali Imran Bokhari, Assistance Professor in Biological Science Department (IIUI) Islamabad Pakistan for valuable comments on the manuscripts.

Authors declared no conflict of interest.

\section{CONFLICT OF INTEREST}

\section{REFERENCES}

[1] P. Pingali, "Westernization of Asian diets and the transformation of food systems: Implications for research and policy," Food policy, vol. 32(3), pp. 281-298, 2007.

[2] F. J. F. Dizon, A. L. Josephson, D. Raju, "The Nutrition Sensitivity of Food and Agriculture in South Asia," The World Bank, 2019.

[3] V. Kiaya, "Post-harvest losses and strategies to reduce them,' Technical Paper on Postharvest Losses. Action Contre la Faim (ACF), 25, 2014. 
[4] E. Bisangwa, "The effects of halving lost and wasted food on food security, water, land and fertilizer resources-A quantitative comparison between developed and less developed regions,'” 2019.

[5] W. E. Bendinelli, C. T. Su, T. G. Péra, J. V. Caixeta Filho, "What are the main factors that determine post-harvest losses of grains?,' Sustainable Production and Consumption, 2019.

[6] C. W. Campbell, “'Tropical fruits and nuts. In Handbook of Tropical Food Crops,’ (pp. 235-274), CRC Press, 2018.

[7] S. J. More, V. Ravi, S. Raju, “Tropical tuber crops" Postharvest physiological Disorders in Fruits and Vegetables,' vol. 1, pp. 719-758, 2019.

[8] P. Timmer, "Food security and economic growth: an Asian perspective,' Center for global development Working Paper, (51), 2004.

[9] G. Rasul, A. Hussain, "Sustainable food security in the mountains of Pakistan: towards a policy framework,' Ecology of food and nutrition, vol 54(6), pp. 625-643, 2015.

[10] A. Matloob, M. E. Safdar, T. Abbas, F. Aslam, A. Khaliq, A. Tanveer, A. R. Chadhar, "Challenges and prospects for weed management in Pakistan: A review,' Crop Protection, 2019.

[11] M. A. Shahzad, A. Razzaq, M. Aslam, M. F. Gulzar, N. Nisar, N., “'Opportunities for Agricultural Trade in the Context of the China-Pakistan Economic Corridor,’ Business and Economic Research, vol 9(1), pp. 263-282, 2019.

[12] M. Shahzad, A. Akhter, A. H. Qureshi, N. Jehan, I. Ullah, M. Khan, “Assessment of post-harvest losses of plum in Swat, Pakistan,’' Pakistan Journal of Agricultural Research, pp 26(3), 2013.

[13] M. K. Bashir, Y. Mehmood, S. Hassan, S. “Impact of agricultural credit on productivity of wheat crop: Evidence from Lahore, Punjab, Pakistan,” Pakistan Journal of Agricultural Science, vol 47(4), pp 405-409, 2010.

[14] I. JUNEJO, M. U. HAQ, “'A technical guide book of banana,’ History, vol 2, pp 4, 2014.

[15] Z. Li, P. Li, J. Liu, 'Effect of mechanical damage on mass loss and water content in tomato fruits,'” Int. Agrophys, vol 25, pp 77-83, 2011.

[16] A. Ahmed, “Crop loss management," DAWN, Retrieved from, 2016.

https://www.dawn.com/news/1300444

[17] M. Khan, J. H. Bae, “'The Environmental Perspectives of Apple Fruit Supply Chain Management in Chitral Northern Pakistan,', International Journal of Supply Chain Management, vol 6(4), pp 1-16, 2017.

[18] Z. Iqbal, M. A. Randhawa, T. Zahoor, M. Asghar, R. Beaudry, “Influence of 1-methylcyclopropene on physicochemical properties of'Gola'and'Surahi'guava (Psidium guajava L.) under air storage,' Pakistan Journal of Agricultural Sciences, pp 55(2), 2018.

[19] K. M. Aujla, M. Abbas, K. Mahmood, S. Saadullah, "Marketing system of fruits, margins and export potential in Pakistan,' Pakistan Journal of Life and Social Sciences, vol 5(1-2), pp 34-39 2007.

[20] E. O. Buyukbay, M. Uzunoz, H. S. G. Bal, "Post-harvest losses in tomato and fresh bean production in Tokat province of Turkey,'’ Scientific Research and Essays, vol 6(7), pp 1656-1666, 2011.

[21] C. Devendra, D. Thomas, “'Smallholder farming systems in Asia. Agricultural systems,'” vol 71(1-2), pp 17-25, 2002.

[22] H. Steinfeld, T. Wassenaar, S. Jutzi, “Livestock production systems in developing countries: status, drivers, trends," Rev Sci Tech, vol 25(2), pp 505-516, 2006.

[23] H. Ali, Z. Fatima, S. Ahmad, “'Fundamentals of Seed Production and Processing of Agronomic Crops,'” In Agronomic Crops (pp. 623-653), Springer, Singapore, 2019.

[24] A. A. Shedayi, M. Xu, J. Gonalez-Redin, S. C. N. Hagist, S. Aslam, N. Khan, "Spatiotemporal assessment and valuation of provisioning ecosystem service of pakistan," Applied Ecology and Environmental Research, vol 17(3), pp 6735-6759, 2019.

[25] F. Hussain, M. Abid, “Pest and diseases of chilli crop in Pakistan A review,' Int. J. Biol. Biotech, vol 8(2), pp 325332,2011 .

[26] D. N. Enyiukwu, A. N. Awurum, J. A. Nwaneri, “Efficacy of plant-derived pesticides in the control of myco-induced postharvest rots of tubers and agricultural products," A review. Net Journal of Agricultural Science, vol 2(1), pp 30-46, 2014. 
[27] M. Iqbal, M. Ahmad, "Science \& Technology based Agriculture Agriculture vision of Pakistan and prospects of growth," In Proceedings of the 20th Annual General Meeting Pakistan Society of Development Economics, Islamabad. Pakistan Institute of Development (PIDE). Islamabad, Pakistan, (pp. 1-27), January, 2005.

[28] B. Shahbaz, T. Ali, I. A. Khan, M. Ahmad, "An analysis of the problems faced by farmers in the mountains of Northwest Pakistan: challenges for agri. Extension,’’ Pak. J. Agri. Sci, vol 47(4), pp 417-420, 2010.

[29] M. Shahzad, A. Tahir, N. Jehan, M. Luqman, “IMPACT OF DIFFERENT PACKAGING TECHNOLOGIES ON POST-HARVEST LOSSES OF STONE FRUITS IN SWAT PAKISTAN,' Pakistan Journal of Agricultural Research, pp 28(1), 2015.

[30] DAWN, "Post-harvest technology in Pakistan, Agriculture," DAWN, Retrieved from, 2001.https://www.dawn.com/news/11785/post-harvest-technology-in-pakistan

[31] G. Campbell-Platt, “'Fermented foods of the world. A dictionary and guide,'” Butterworths, 1987.

[32] M. Bourne, "Post-Harvest Food Losses-The neglected dimension in increasing the world ood supply,". 1977.

[33] S. M. McCurdy, J. D. Peutz, G. Wittman, “'Storing food for safety and quality,” 2009.

[34] H. R. Alavi, A. Htenas, R. Kopicki, A. W. Shepherd, R. Clarete, "Trusting Trade and the Private Sector for Food Security in Southeast Asia,' World Bank Publications: Washington, DC, USA, 2012. 